\title{
Fixing Asia’s Flawed Politics
}

"The Communist Party are the lawmakers, but they do not follow the law, nor respect the constitution," once said Chinese dissident artist Ai Weiwei. ${ }^{1}$ "The problem is that the Party does not trust people, and is afraid of their power ... The Party wants to take control of everything, even in areas it is incapable of dealing with." And yet today the Chinese Communist Party (CCP) now seems more firmly in control of China than ever.

\section{Asia's Democracy Deficit}

Democracy has very shallow roots and many enemies in Asia, and not only in China. Indeed, not one Asian country would have a "full democracy", according to the Economist Intelligence Unit (EIU). ${ }^{2}$ Asia's most democratic countries-Japan, Korea, India and Taiwan-are classified as "flawed democracies". And not one Asian country would have a "good situation" when it comes to freedom of the press, according to Reporters Without Borders, a media watchdog. ${ }^{3}$ The freest press in Asia would be in Taiwan, which was ranked only 45 th in the world out of the 180 countries covered, and placed in the "satisfactory situation" category.

In sum, mature democracy is struggling to take hold in Asia, which is compromising the lives and freedoms of Asia's citizens, and imposing great costs on the economy as well.

The parlous state of democracy in Asia is perhaps not totally surprising, as the region was traditionally governed by communist autocracies, 
military dictatorships and paternalistic strong-men. And overcoming the past is never easy. But political scientists are right to be disappointed with the state of democracy in Asia. There has been a long series of modernization theorists starting with Seymour Martin Lipset, ${ }^{4}$ who have predicted that economic development together with rising middle classes, education and urbanization would foster democratization. ${ }^{5}$ And the successful transformation of Korea and Taiwan from authoritarian regimes into democracies raised hopes that other Asian countries would follow suit.

Many have also thought that encouragement from the international community, especially from "democracy evangelists" like the US, would motivate countries to democratize. Indeed, as emerging economies climb the development ladder, they can be attracted to becoming respected members of the international community. In the case of Korea, joining the Organisation of Economic Co-operation and Development (OECD) was a great "badge of honor", as the OECD is the group of rich, developed countries which stands for the principles of market economy, pluralist democracy and respect of human rights. ${ }^{6}$

More recently, many analysts have also thought that the advent of the Internet could fuel democratization. The Internet and social media are providing citizens in many non-democratic countries with unprecedented access to information and with effective tools for social mobilization. Indeed, Asia's youth elite is typically tech-savvy, highly connected through social media, educated overseas, international in outlook, self-confident, and as I have seen through teaching many Asian students, they are all too aware of the moral bankruptcy of many of their own leaders.

But democracy is struggling to take root in many Asian countries where the preconditions should be ripe for democracy. And democracy is not maturing as countries climb the economic development ladder. Traditional elites are engaged in a strong rearguard action in their defense of authoritarian or single party regimes. ${ }^{7}$

The poverty of democracy in Asia is clearly evident from the EIU's Democracy Index 2016 which surveys 167 countries. Asian countries find themselves in the flawed democracies, hybrid regimes or authoritarian categories, rather than the full democracy category where most Western countries are placed. This index recognizes that there is more to democracy than holding elections ("electoral democracy"). And so it should. Asia is replete with countries that administer shonky elections, and have weak institutions and rule of law. In addition to the electoral process and pluralism, the EIU index takes into account other factors like the 
functioning of government, political participation, political culture and civil liberties.

To help understand the state of region's politics, we would like to propose the following classification of Asian countries:

- Japan and Korea, Asia's most democratic countries, which are ranked 20th and 24th respectively by the EIU, are oligarchic democracies where big business has a large influence over policy-making through collusive relationships with government.

- Hong Kong, Malaysia and Singapore (ranked 68th, 65th and 70th) are pro-business economies which have very open markets, and are much more globalized than Korea or Japan. But these countries also have very much weaker democratic foundations than either Korea or Japan.

- Policy-making in Taiwan (33rd), Hong Kong (68th), Cambodia (112th) and Laos (15lst) is subject, either willingly or unwillingly, to substantial influence from Communist China which is seeking to establish a system of client states in its neighborhood. In recent times, Sri Lanka and Myanmar have made some efforts to escape the tight clutches of Beijing.

- Asia has a large number of weak and fragile democracies which are riddled with corruption and burdened by ineffective states, namely India 32nd, Indonesia 48th, Philippines 50th, Mongolia 61st, Sri Lanka 66th, Bangladesh 84th, Nepal 102nd and Myanmar 113th.

- The military has long played an important role in Asian politics, especially in three countries where the military still plays an outsized role as it controls civil governments-Thailand (100th), Pakistan (111th) and Myanmar (113th).

- Lastly, there are three staunchly authoritarian Asian countries-Vietnam (131st), China (136th) and North Korea (167th). While there are some forces pushing for more transparency, accountability, rule of law and even democracy, these authoritarian regimes remain firmly in control with virtually no immediate threat to their viability.

\section{What's Holding Back Asia’s Democratization?}

There are many factors which are responsible for the parlous state of democracy in Asia. For example, many in Asia's middle and upper classes are not great supporters of democracy, as they have been substantial 
beneficiaries of Asia's rapid economic development, and rising inequality. Rather, they are supporters of the status quo, and often fear the possible impact of allowing the whole population to have a say in their nation's politics. They often look upon poorer, rural populations as uneducated country bumpkins, who represent a potential threat to their privileged position.

Some members of Asia's middle and upper classes (especially from China) want democracy and freedom, but achieve this by opting out and migrating to countries like the US, Canada, Australia and New Zealand. Recent years have seen large flows of Asian migration to these countries, ${ }^{8}$ together with massive investments in real estate and illicit financial outflows.

The Internet and social media have proved to be two-edged swords in the quest for democracy. While they have greatly improved access to information, many Asian governments have responded by imposing censorship controls on the Internet (like China's great firewall), by disseminating propaganda through the Internet, and by using the Internet for surveillance of its citizens. The Internet and social media are now a dynamic battleground where activists are working to get around government controls and where both activists and governments are competing to get their messages out.

Desperate elites can also go to enormous lengths to hold onto power, as in case of Malaysia with its repeated prosecution of opposition leader Anwar Ibrahim. While the ruling party, the Barisan Nasional (BN), always wins national elections, its majorities have been declining. So in recent years, it has been involved in a dirty and violent struggle to hang on to power through "intimidation, electoral fraud and gerrymandering", according to Joshua Kurlantzick. ${ }^{9}$

Western democracy is painted in a bad light in many authoritarian countries, especially in China, with the British referendum to leave the EU (Brexit) and the election of Donald Trump to the presidency of the US, being cited as evidence of the shortcomings of Western democracy. In response to the US State Department's annual reports on human rights across the world, ${ }^{10}$ the Chinese government issues its own report where it castigates the state of human rights in the US. In China's 2016 report, ${ }^{11}$ it said "Wielding 'the baton of human rights,' it [the US] pointed fingers and cast blame on the human rights situation in many countries while paying no attention to its own terrible human 
rights problems." It added "With the gunshots lingering in people's ears behind the Statue of Liberty, worsening racial discrimination and the election farce dominated by money politics, the self-proclaimed human rights defender has exposed its human rights 'myth' with its own deeds."

Most Western governments and business now widely accept and tolerate China's one-party rule and all the human rights abuses that go with it. The attraction of China's big market and growing political power mean that most criticism of China is very softly done. Some companies are even willing to adapt their products to meet China's non-democratic concerns. Reports that Facebook has worked on special software so it could potentially accommodate censorship demands in China are particularly disturbing.

There was a time when most political scientists believed that China's growing integration into the world economy would foster a convergence of social and political culture with the West. If anything, the reverse has happened whereby Western dependence on Chinese markets, and political cooperation for issues like North Korea and climate change has eased external pressure on China's one-party system. And China has been able to use other countries' dependence on its market to impose economic sanctions on them to express its displeasure at their actions, as Japan, Korea and the Philippines have discovered.

Populism is another political force that is leaving its mark in Asia, not only in the US and Europe, and not always to the benefit of democracy. It should be hardly surprising that political leaders are appealing to the popular masses by criticizing traditional elites, with President Duterte of the Philippines being the prime example (Thailand's Thaksin Shinawatra was an earlier case). Duterte promised and is now practicing an illiberal form of democracy through his murderous war on drugs and crime where human rights abuses and disrespect for the rule of law are the order of the day.

Against this background, we will examine in greater detail several cases of Asia's flawed politics in the following sections: will China democratize, oligarchic democracy in Korea and Japan, the Philippines' gyrating populism and military politics in Myanmar and Thailand. In the final sections, we will explore the debate about whether authoritarian regimes like China's are more efficient than messy democracies like India's, and the economic benefits of democracy. 


\section{Will China Democratize?}

There is perhaps no issue that irritates the Chinese leadership more than America's obsession about whether, when and how China will become a democracy. It seems natural for America that democracy will be China's final political destination, and that single party rule by the CCP is just a transitional situation. It is perhaps part of the American mindset that we should all ultimately become like them. But the Communist Party believes that it should be in power forever, and is working toward that end.

It is easy for Western observers to underestimate the power and strength of the Chinese state. Indeed, China was the first country in the world to create a modern state-almost 2300 years ago and some $1700-1800$ years before Europe-as political scientist Francis Fukuyama has argued. ${ }^{12}$ But it is also true that China has never had the rule of law, by which the country's highest political authority should also obey the law. Even today, the Communist Party is a law unto itself, and China's judiciary is highly politicized and corrupt. "Constitutionalism" is a taboo subject in China.

Nor have China's rulers ever been subject to "downward accountability" to the country's citizens through democratic elections. This situation was facilitated by the feudal nature of Chinese society through much of its history when the vast majority of Chinese citizens were poor farmers living in rural areas. Dramatic economic and social changes have totally transformed China's political context, as Chinese citizens are now better educated, more prosperous and urbanized, and they have breathed the fresh air of economic freedom and opportunity. The challenge for China's government has thus been how to adapt single party rule to this new context.

Just a decade after Deng Xiaoping began opening the economy, the CCP was shaken to its bones by the near-death experience of the 1989 Tiananmen Square student protests. Now more than 25 years after, the CCP still shudders on the anniversary of the "June Fourth Incident". It clamps down on social and other media, and the movement of activists, and it exerts a maximum of repression of any possible commemoration or even discussion of the event.

China's rehabilitation following this horrendous massacre took a few years. Deng Xiaoping's “southern tour" of 1992, when he relaunched China's economic reforms, marked the next phase in China's economic, social and political development. The post-Tiananmen phase of China's development proceeded on the basis of a "social contract". The implicit 
deal was that the Chinese population would accept the authoritarian rule of the CCP because it was very successful in engineering economic growth, the key to poverty reduction and prosperity.

This became the basis of the CCP's legitimacy, "performance legitimacy". And it also earned the admiration of many Western and other observers who were impressed with the Chinese government's capacity to make big decisions, and implement large projects like the Three Gorges Dam in the face of large opposition and environmental destruction. Quashing human rights seemed to be a worthwhile price to pay for economic efficiency, especially when compared with the inefficiency of India's chaotic democracy.

Following the Tiananmen Square incident, the CCP further bolstered its role as the legitimate representative of the Chinese civilization and people with a highly nationalistic discourse. One lesson that the Chinese leadership drew from the Tiananmen Square incident was that the Communist Party needed to make greater efforts to promote nationalism to improve support for the Party. Students and citizens were taught how the Communist Party was leading China's recovery from its "century of humiliation" (from the opium wars to the end of the civil war in 1949).

National victimhood has thus become a key narrative. But victimhood has morphed into resentment and the desire for revenge which is evident in much of its international behavior from cyber-hacking to claiming sovereignty over the distant South China Sea. China is now not only in the midst of an economic recovery, but also the restoration of national pride, and the CCP is leading this battle.

The post-Tiananmen period has seen a great expansion in economic and personal freedoms. Many young Chinese have been allowed to study overseas, especially to the US. More recently, the numbers of Chinese traveling overseas as tourists have grown to the point whereby China has the world's highest number of international tourists, with Japan becoming a very popular destination. Chinese citizens also enjoyed increasing access to information and participation in social media thanks to the Internet. Indeed, during the regime of President $\mathrm{Hu}$ Jintao and Premier Wen Jiabao (2002-2012), it seemed that China has loosening up its political controls. Premier Wen even made some encouraging speeches on China's need for political reform.

But toward the end of the $\mathrm{Hu} /$ Wen regime, and especially under the current President Xi Jinping, political freedoms have moved backward, repression has intensified and China has become more assertive in its 
relations with both its neighbors and the West. China is in the midst of a "great leap backward" according to James Fallows. ${ }^{13}$ "The country has become repressive in a way that it has not been since the Cultural Revolution," writes Fallows.

Increased repression is evident everywhere-be it in tighter controls over the Internet; instructions to the media that it must "serve the Party"; warnings by the Chinese leadership that dissent will not be tolerated; stiffer curbs on freedom of expression, association, assembly and religion; prosecution and jailing of lawyers and civil society leaders; extraterritorial actions against perceived enemies of the regime such as the abduction of booksellers from Hong Kong; and discrimination against foreign enterprises and all things foreign. Chinese leaders now explicitly reject the universality of human rights, seeing them as "foreign infiltration". ${ }^{14}$ And the Chinese military's assertiveness vis-à-vis neighbors has greatly eroded trust, increased tensions and seen many countries turn to the US for support.

What is behind this great leap backward? Factors driving repression include the global financial crisis which highlighted the fragility of China's export-oriented economic model, public disgust at the Communist Party corruption and rising inequality, the appalling local environment, shudders at the sight of the Arab Spring and rising social unrest. According to one estimate, the number of public protests in 2010 was of the order of 180,000 and $230,000 .{ }^{15}$ And while external assertiveness can be used to camouflage domestic fragilities, the Chinese leadership also interpreted the global financial crisis as a clear sign of the decline of the West, and the success of the 2008 Beijing Olympics as symbolic of Chinese ascendancy. They also saw US President Obama's diplomacy-first approach to foreign relations as a sign of weak leadership it could take advantage of.

Xi Jinping's ascension to the presidency of China and head of the Communist Party in late 2012 /early 2013 was also marred by factional infighting and a murderous scandal involving his nemesis, Bo Xilai, who was prosecuted and now lives in jail. Xi thus began his presidency with a CCP more divided between factions and clans than since Tiananmen Square. In his first five-year term at the helm of China, Xi Jinping has focused almost entirely on fighting corruption which he believes is a liveor-death issue for the Communist Party.

Xi's anti-corruption campaign has been vast, implicating thousands of both flies (low-level bureaucrats) and tigers. Although Xi's anti-corruption drive has merely scratched the surface, he has exposed a complex system of 
patronage which holds the CCP together. The anti-corruption campaign has equally been a strategy for eliminating Xi's political enemies and rivals to "consolidate power". And in doing so, Xi has accumulated more power than any Chinese leader since Deng Xiaoping and perhaps since Mao Zedong-although many locals think that a comparison with Russia's Putin might be more apt. At the same time, the deeper that the anticorruption campaign digs, the more enemies Xi makes. President Xi has also launched his own propaganda campaign in the form of the "Chinese Dream", which Xi has described as the "great rejuvenation of the Chinese people ... improvement of people's livelihoods, prosperity, construction of a better society and a strengthened military".

Analysts have been predicting the possible demise of the CCP or the impending democratization of China for many years. In 2001, Gordon Chang predicted the "coming collapse of China". ${ }^{16}$ In 2013, Minxin Pei argued that China's GDP per capita was already well into the "zone of democratic transition", and above those of Korea and Taiwan on the eve of their democratic transitions. ${ }^{17}$ Minxin Pei has also argued that President Xi's war on corruption could hasten the CCP's fall. ${ }^{18}$ And in 2016, David Shambaugh argued "the Chinese Leninist system [is] once again in a state of atrophy and inexorable decline ... Hard Authoritarianism is a recipe for economic stagnation, social instability, and the political decline of the Chinese Communist Party." Unless there is a return to Soft Authoritarianism, which is unlikely, "secular stagnation will continue, the reforms will continue to stall, and the CCP will gradually lose its grip on power". ${ }^{19}$ There is much that the CCP could do to return China to "Soft Authoritarianism" or even transfer it into a "Semi-Democracy" like Singapore, without even necessarily giving up its monopoly on power. But this does not seem to be on the cards.

For its part, the CCP is openly worried that the stability of the Party will be undermined by Western ideas and "universal values" like constitutional democracy, human rights, media independence and transparency, which it regards as being responsible for the "color revolutions" in Eastern Europe and the Middle East. It is also worried about the large flows of outward migration by China's elites, as well as massive capital flight. And yet, despite all the doomsdayers, there are also many who believe that the CCP will hang on to power for at least the foreseeable future. They argue that much of the middle class, which has benefited from China's economic miracle, still support the CCP, and most certainly fear the consequences of instability. Further, over 85 million people are members of the CCP, who 
are important stakeholders in the existing system. The CCP "co-opts" into the Party members of social elites, like academics, professionals and entrepreneurs. This is a way to neutralize social groups who are normally forces for democratization.

China's internal security service and the People's Liberation Army are arguably strong enough to keep things under control. A massive domestic security budget (more than the military budget) is employed to maintain social stability. And China reportedly has an "Internet police force" of some 2 million, who are constantly monitoring, censoring and spreading propaganda on the Internet. Most certainly, President Xi is firmly intent on holding onto power, and has no intention implementing any democratic reforms. $\mathrm{Xi}$ has analyzed the demise of the Soviet Union, and concluded that, in contrast to Gorbachev, the CCP must stand firm. Any political reform is about the CCP reforming itself, not reform of the political system.

What does the future hold for China? Only time will tell. But as David Shambaugh said, we should not expect developments in China to be linear- "Sharp changes of course have occurred with some regularity throughout China's history." In the short term, we can expect President $\mathrm{Xi}$ to tighten even more his grip on power. He will be anointed for second five-year term at the 19th National Congress of the Communist Party of China in October 2017, when he will also stack the Politburo Standing Committee with loyalists. Policy will be geared to achieving the goal of "building a moderately prosperous society in all respects and double the 2010 GDP and per capita personal income by 2020 ". And Xi will invest great political energy and capital in the 2021 celebrations of the centenary of the founding of the Communist Party.

\section{Korea's Corrupt Democracy}

The 2017 impeachment of Korean President, Park Geun-hye, and prosecution of Lee Jae-yong, the head of Samsung, highlight Korea's deep corruption. But they are also testimony to the strength of Korea's democratic institutions.

Korea experienced a horribly authoritarian period in the 1960s and 1970s under President Park Chung-hee, the father of the impeached Korean president. But Korea's political space was always contested-especially by two individuals who became president in the 1990s, Kim Youngsam, and Kim Dae-jung. And protests by Korea's well-educated students were also a recurrent feature. 
In 1987, in the midst of widespread student and trade union protests, designated presidential successor Roh Tae-woo made the historic decision to hold elections, which he won. Korea's democratic transition was confirmed by the election in 1992 of President Kim Young-sam from the center-right-wing Democratic Liberal Party. This transition was most significant in that Kim, a democratic activist, succeeded Roh, who was a former army general, closely linked to Korea's authoritarian past.

The 1997 election of President Kim Dae-jung from the center-leftwing party, National Congress for New Politics, demonstrated the capacity of Korea's new democracy to accept the alternance of power between right- and left-wing presidents. Kim Dae-jung had survived years in jail and several assassination attempts, and is often referred to as "Asia's Mandela". ${ }^{20}$ The growing maturity of Korea's democracy was demonstrated by the election of another center-left president, Roh Moo-hyun, in 2002, followed by two right-wing presidents, Lee Myung-bak (elected 2007) and Park Geun-hye (elected 2012). As Freedom House has observed, "Political pluralism is robust [in Korea], with multiple parties competing for power and succeeding one another in government." 21

Korea's transformation from an authoritarian regime to a democracy represents one of Asia's greatest post-war achievements. In the space of a generation, Korea moved from being a recipient of foreign aid to being a member of the OECD, the club of advanced democracies and aid donors. As former OECD Secretary General Donald J. Johnston said, "Korea has set an example for other emerging market economies to follow." 22

But Korea's democracy is still very much tainted by the country's authoritarian past. Freedom of the press is greatly compromised, and getting worse, according to Reporters Without Borders, which ranked Korea only 70th in the world in 2016 (out of the 180 countries surveyed), ten places lower than in 2015. ${ }^{23}$ The Park government did not entertain criticism, and threatened media independence. Public debate about relations with North Korea is taboo. Korea's spy agency has now admitted that, in the lead-up to the 2012 presidential elections won by Park Geun-hye, it had cyber-teams spreading pro-government opinions and suppressing anti-government views.

And most troubling, as of March 2016, 74 trade unionists including the President of the Korean Confederation of Trade Unions (KCTU) were in prison. Five hundred and four other KCTU members were charged with "obstruction of traffic" in relation to a demonstration held in 2015. When Korea joined the OECD in 1996, it committed to reform its labor 
law to bring in line with the standards of the International Labour Organisation (ILO). Yet, basic labor rights, including the right to organize and to bargain collectively, are not observed in today's Korea, according to Trade Union Advisory Committee (TUAC) to the OECD. State interference in trade union activities remains the norm.

"Regrettably, twenty years after its accession, Korea is still far from having built a system of industrial relations based on ILO standards that can manage conflict, reduce inequality and ensure social progress. In the past three years, repression against unions and the criminalisation of their activities appear to have returned," said John Evans, TUAC General Secretary. ${ }^{24}$

Corruption is also endemic in the highest levels of Korean political and business life. Indeed, all of Korea's democratically elected presidents or their families have been implicated in corruption scandals. For example, at a time of corruption scandals involving his family, Roh Moo-hyun committed suicide in May 2009. And President Kim Dae-jung's historic peace summit in June 2000 with North Korean leader, Kim Jong Il, was also tainted by suicide. Hyundai's Chairman Chung Mong Hun took his life while he was facing criminal charges for his part in a deal to allegedly pay a bribe of $\$ 500$ million to Kim Jong Il for participating in the summit.

Even by Korean standards, the corruption scandal that brought down the presidency of Park Geun-hye in 2016-2017 was bizarre. President Park's close friend Choi Soon-sil, a "Rasputin-esque" figure and daughter of a shadowy cult figure, extorted at least $\$ 70$ million dollars from Korea's chaebols for two of her foundations-allegedly in collusion with Park. Samsung, the veritable symbol of Korea, was also dragged into this scandal. In August 2017, its head, Lee Jae-yong, was sentenced to five years in prison for bribery and embezzlement charges. Samsung allegedly gave $\$ 38$ million to Choi in return for favors, notably government support for a merger of two Samsung affiliates in 2015 that helped Lee inherit corporate control from his incapacitated father.

President Park's scandal is even murkier. She was seemingly possessed by Choi who is alleged to have dictated or influenced all manner of official and personal decisions taken by Park. Choi would have had access to confidential documents and information of the president. The scandal was allegedly broken by Choi's "toyboy" who apparently fell out with her. Choi has been charged with abuse of authority, coercion and fraud. ${ }^{25}$

As this scandal became public from October 2016, there were massive protests against President Park every Saturday evening in Seoul for two months. On 9 December 2016, the National Assembly passed a motion 
recommending impeachment of Park. Korea's leadership was put in the hands of an Acting President, Hwang Kyo-ahn. Then on 10 March 2017, the Constitutional Court unanimously upheld the impeachment. Park has lost her presidential immunity and is now being prosecuted in a criminal trial.

In May 2017, Mr. Moon Jae-in, head of the left-of-center Democratic Party, won Korea's presidential election. Like liberal presidents before him, Moon would like to reopen dialogue and cooperation with North Korea, in conjunction with tough sanctions. Although this puts him at variance with Donald Trump, Trump's tough talk seems increasingly empty, as virtually all he is doing is begging China to solve his North Korea problem.

As a liberal, President Moon will likely be more conciliatory with China, to the displeasure of the US, and also tougher with Japan, again to the displeasure of the US, which has been encouraging its two Asian allies to improve cooperation with each other. At the moment, relations with China are tense, as China is objecting to the US' installation of the Terminal High Altitude Area Defense (THAAD) system, ostensibly to protect Korea from missiles from the North. China is concerned that it will enable the US to spy into its territory, and imposed economic sanctions on Korea.

As Korean leaders including Park have proposed in the past, President Moon will need to break the cozy ties between the chaebol and the government, which are at the heart of Korea's big corruption problem. One heartening point that we can draw from President Park's corruption scandal is that Korea's democratic institutions have functioned well, with Park having to face up to the will of the people and the rule of law. They give hope that Korea could reform its democracy and come out stronger in the end. The widespread protests are also perhaps evidence that Korean citizens are democratic at heart, something we cannot yet say about Japan.

\section{Japan's Oligarchic Democracy}

Japan's oligarchic democracy has much in common with Korea's, but it also has important differences. In its long history as a nation, Japan had virtually never been a democracy, apart from a modest experience in the 1910 s and 1920s at the time of emperor Taisho ("Taisho democracy"). ${ }^{26}$ Authoritarian, fascist, feudal and/or military regimes were the norm. After Japan surrendered in defeat at the end of World War 2 some 70 years ago, 
the US post-war occupation regime under General Douglas MacArthur instituted democracy in Japan. Unlike France, Korea and many other cases, the Japanese people did not fight for their democracy. This may be why Japan has been a virtual one-party state for much of the post-war period, with the right-wing Liberal Democratic Party (LDP) holding nominal power.

Nevertheless, political power has been substantially exercised by Japan's powerful bureaucracy, which managed the "iron triangle" of bureaucrats, business and politicians, that engineered Japan's miraculous recovery from the ashes of military defeat. Today, we may marvel at Japan's excellent infrastructure as testimony to the great efficiency of the iron triangle. But public investment in infrastructure also served other roles, notably financing Japan's electoral system through kickbacks from construction companies to politicians, and buying public support for LDP politicians. And Japan's international corporate success stories like Toyota grew up behind walls of protection against international competition, which enhanced their support for the iron triangle system. While gerrymandering of rural political constituencies, and large financial support for Japan's farmers, further bolstered support for the LDP.

The credibility of LDP-led government gradually eroded over the years, as a result of a series of outrageous corruption and other scandals, and its inability to respond effectively to the bursting of Japan's bubble economy in the early 1990s. In 2009, the LDP was swept from power in a landslide electoral victory by the left-wing Democratic Party of Japan (DPJ), which won $64 \%$ of the parliamentary seats. This change of power raised many hopes that Japan had finally become a true democracy. But the DPJ's tenure was a great disappointment. It was characterized by inexperience, incompetence, conflict with the bureaucracy which then undermined the government, and conflict/misunderstandings with the US concerning its military bases in Japan, which are still home to some 50,000 troops.

Perhaps the greatest blunder of the DPJ government was the purchase of the Senkaku Islands from their private owner. As the sovereignty of these islands is still disputed with China, this act provoked an outsized reaction from the Chinese government, which continues to this day. The poor response to the March 2011 triple crisis of earthquake, tsunami and nuclear disaster was further evidence of the systemic weakness of Japan's system of governance. As the Fukushima Nuclear Accident Independent Investigation Commission concluded, the nuclear crisis was not a natural 
disaster, “...this was a disaster "Made in Japan”. Its fundamental causes are to be found in the ingrained conventions of Japanese culture: our reflexive obedience, our reluctance to question authority, our devotion to 'sticking with the program', our groupism and our insularity." ${ }^{27}$ The inadequate regulation and supervision of Tokyo Electric Power Company (TEPCO), another major cause of the disaster, also highlighted the role of the nuclear iron triangle ("nuclear village"), where business and political interests were ganging up against citizens' interests. TEPCO is, for example, a large donor to the LDP and other organizations.

In the space of three years, the DPJ had three leaders, which meant that there was very little policy continuity and very little was achieved. And so it was that LDP was swept back into power in December 2012, under the leadership of Prime Minister Shinzo Abe. But this was not a real victory for the LDP. It was a rejection of the DPJ. The promise of democracy, raised by the 2009 DPJ victory, has faded in the distance. The DPJ was decimated in the 2012 election and is now a spent force as it won a mere $12 \%$ of the parliamentary seats. The LDP, and its junior coalition partner, the "Komeito" Party (a Buddhist party), now govern without any effective opposition. As in much of the post-war period, Japanese political competition mainly takes place behind closed doors between the different factions within the LDP, a similar situation to the one-party rule in Communist China. And for the moment, the hyperactive Mr. Abe has been able to ward off opposition from rival faction leaders.

Although Mr. Abe's principal mandate is to revive the economy through Abenomics, he has in fact spent much more energy on other issues, for which there is much less public support. ${ }^{28}$ Abe has pushed through a change in Japan's post-war pacifist security policy in the area of "collective self-defense", by reinterpreting Article 9 of the Constitution to the horror of most legal scholars. This would enable the Japanese military to come to the defense of allies, notably the US. Abe's dream is to revise Japan's pacifist constitution by which the "Japanese people forever renounce war as a sovereign right of the nation and the threat or use of force as means of settling international disputes" and that military forces "will never be maintained".

Today, Japan's democracy is bedeviled by many factors-some old and some more recent. Japan has reverted to being a virtual one-party state dominated by the LDP and its leader, Shinzo Abe. Japan's national political opposition may never have been weaker than it is today. Japan has never had a truly free and independent media, and this continues to be 
the case. The press clubs ("kisha clubs") that each government ministry operates foster unhealthily cozy relations between journalists and government officials, which inhibit critical reporting. The national broadcaster, $\mathrm{NHK}$, is now clearly under the government's thumb. NHK journalists have quietly told me they are not allowed to criticize the government. Some commentators have suggested that NHK behaves like a national broadcaster in Communist China. And like Korea, Japan continues to be plagued by high level corruption in the political and business spheres, even though at the street level, the Japanese people are perhaps the world's most honest.

Japan's oligarchic democracy is very costly to the country in many ways. Japan's lost decades since the 1990s financial crisis are the direct result of vested interests blocking the necessary structural reforms, and of sluggishness in responding to the unfolding demographic drama. The government is reluctant to hold open discussions on national security issues, with most important decisions being pushed through behind closed doors. And decisions on questions like the future of nuclear energy are often taken in defiance of public opinion.

Only the Japanese people can make Japan a real democracy by becoming more politically active and assertive. But their society leaves them illequipped to do so for many reasons. For example, Japan's deeply entrenched culture of social hierarchy means that there is insufficient questioning of authority. Its education system is based on rote learning and memorization, rather than critical thinking and analytical skills, leaving youth insufficiently capable of analyzing the world around them. Fervent nationalism and an exaggerated sense of cultural uniqueness inhibit the capacity of Japanese citizens to draw lessons from the experiences of other countries. And Japan's conformist and conservative society is sustained by what Yoshio Sugimoto calls a system of "friendly authoritarianism". ${ }^{29}$ "Japanese society has various forms of regimentation that are designed to standardize the thought patterns and attitudes of the Japanese and make them toe the line in everyday life," according to Sugimoto.

\section{Philippines' Populist Temptation}

The Philippines' modern political history is tainted with populism and turbulence. And yet, in the 1950s, the Philippines was one of Asia's most promising young democracies. But the country's leadership fell into the 
clutches of President Ferdinand Marcos from 1965 to 1986, who hijacked its fragile democracy and instituted martial law for a decade. Marcos and his cronies wreaked havoc on the Philippine economy, just at the time that Asia's miracle economies were taking off. During Marcos' term, national debt grew from $\$ 2$ billion to almost $\$ 30$ billion, which Filipinos are still repaying to this very day. Marcos his family and cronies amassed an estimated \$10 billion. Human rights abuses were widespread, as opposition figures were murdered and tortured. The Philippines thus became the sick-man of Asia.

The populist People Power Revolution of 1986 restored democracy. Then in 1998, Joseph Estrada, a former actor, was elected President, as a man of the people, with the largest vote margin in Philippine history. But charges of corruption saw his political demise in another extraconstitutional People Power movement in 2001.

Since the restoration of democracy, the Philippine economy has slowly been clawing its way back. The economy improved greatly during the presidency of Benigno Aquino (2010-2016), when it has been one of the world's fastest growing economies, with an annual growth rate of close to $6 \%$. Key drivers of the economy were migrants' remittances and the business process outsourcing sector. The Philippines also experienced a welcome boom in foreign direct investment. ${ }^{30}$ Aquino won plaudits from the international community for tackling corruption, and improving governance. For example, the Philippines was rewarded by the major international credit rating agencies-Moody's, Standard \& Poor's, Fitch and the Japan Credit Rating Agency - with upgrades in its sovereign credit ratings to "investment grade".

But Filipinos remained rightly frustrated, particularly when comparing their country with its neighbors like Malaysia and Thailand which are way ahead in terms of GDP per capita and poverty reduction. Lack of opportunity has pushed many talented Filipinos to find work overseas, all too often in jobs well below their skill level and in dangerous countries in the Middle East- $10 \%$ of the population lives overseas. The appalling state of the Philippines' infrastructure is evident as soon as you arrive at Manila airport, and then make your way, at a crawling speed through traffic jams, to your hotel.

And the Philippines is quite simply a very dangerous country. ${ }^{31}$ Violent crime is a significant problem, especially theft, physical assault, robbery, pickpocketing, confidence schemes, acquaintance scams and credit card fraud. Carjacking, kidnappings, robberies and violent assaults also occur 
sporadically. Victims of kidnapping can be beheaded, if their family doesn't pay a ransom. Terrorist attacks can occur at anytime, anywhere in the Philippines, including in Manila. Drug abuse and trafficking have been major problems in the Philippines, especially the reported usage of "shabu", the street name of methamphetamine.

The regrettable reality is that the Philippines is neither a mature nor an effective democracy, and has never had a strong and effective state or leadership. The EDSA People Power Revolution of 1986 only returned to power the old Philippine oligarchy which is mainly interested in its protecting privileges. As Philippine political scientist Richard Heydarian has argued, the Philippines' dysfunctional democracy is dominated by the country's oligarchic elites. ${ }^{32}$ "The vast majority of legislators (70 percent) hail from political dynasties, dwarfing even comparable Latin American countries like Mexico (40 percent) and Argentina (10 percent)," said Heydarian. And the Philippines' elites have also been milking the economy dry in recent years, as Heydarian notes- " $76 \%$ of newly-generated wealth was swallowed by the 40 richest families, the worst kind of growth concentration in Asia."

It is perhaps not surprising that the Philippine people should have voted populist firebrand Rodrigo Duterte as their new president in 2016. Like Donald Trump, this man of the people, with his tough-talking style, seems much more authentic and entertaining than the representatives of the establishment. In this feudalistic nation, with an uncaring elite and disenfranchised masses, personalities have always mattered more than policies in national politics. Duterte, also known by sobriquets like "Duterte Harry" and "the Punisher", promised to tackle head on the country's chronic problems of drugs, criminality and corruption. As Mayor of Davao City on the southern island of Mindanao for over 20 years, Duterte brought peace and security to this city, in the Philippines' most violent and unstable region. However, Duterte also admitted to having links to Davao death squads which conducted extrajudicial killings of over 1000 alleged drug traffickers, criminals, gang members and other lawless elements.

Since assuming the presidency, Duterte has launched his war against drugs with a vengeance inviting citizens and vigilante groups to kill criminals. Various reports suggest that over 8000 people have been killed, and many more thousands have turned themselves in. As the US, Europe, the $\mathrm{UN}$ and others criticized his manifest abuses of human rights, Duterte merely responded with threats and insults. He has also been pursuing a 
more "independent" foreign policy, by forging closer relations with China and Russia, and reducing the country's longstanding reliance on the US.

While Duterte is losing friends in the international community, he is very popular at home, where people can already feel an improvement in the local security environment. Families and friends of innocent victims do not, as yet, seem to pose a threat to his popularity, as most of those killed come from poor and powerless backgrounds. Overall, Philippine citizens have been willing to trade some of their hard-won human rights and freedoms for the promise of greater security from a brutal crackdown on crime, drugs and corruption in this dangerous country. Filipinos have succumbed to "authoritarian nostalgia", as they look back to the mythical good old days of strong leadership under President Marcos.

As impressive as Duterte's war on drugs and criminality may seem, it is deeply flawed in many ways. Most victims of the violent crackdown have been small-time drug users and sellers, with big drug lords, many of whom come from China, escaping scot-free. There have also been many innocent victims. And the Philippines does not have enough facilities to treat drug users, nor even sufficient jail space to house more criminals. It may be just a matter of time before Filipinos decide that wholesale murder is not a solution to the nation's drug problem.

There is another war, a more important one, that the Philippines needs to win, and that is the war against poverty, which is a major root cause of the Philippines' drug problem. Duterte does have some constructive proposals, like boosting infrastructure spending. But progress has been slow.

More recently, the fragility of the Philippine state has been exposed by the infiltration of Islamic State (ISIS) ideology into the southern island of Mindanao, and the capture of the southern city of Marawi by Islamic extremists. While Islamic terrorism has long been a problem in the southern Philippines, many observers, including Australia's foreign minister Julie Bishop, are now concerned that ISIS might seek to declare a caliphate in the southern Philippines, and that Southeast Asia could become the new battleground against ISIS.

There are also grave concerns that Duterte's new love affair with China, and use of Chinese loans to finance much-needed infrastructure, could lead to a substantial rise in the country's debt, and an erosion in national sovereignty, as potential debt bondage could leave the country vulnerable to Chinese geopolitical interests. Thailand is another country that has been vulnerable to populism and political instability. But its government has been more effective in promoting economic development. 


\section{Thailand, The Land of a Thousand Coups}

Thailand's politics have long been dominated by the military and the monarchy, which have ensured that the economy serves the direct interests of the Bangkok elites (the monarchy, military, the judiciary, the senior civil service and business leaders). Governments have typically been kept weak and vulnerable, and regularly deposed by the military.

The "land of smiles" has nevertheless enjoyed great success over the past few decades. Thailand's GDP per capita leapt from $\$ 4300$ in 1990 to $\$ 16,900$ in 2016. The country ranks 34th in the World Economic Forum's Global Competitiveness Index. And extreme poverty has been virtually eliminated. Keys to Thailand's success have been its ability to attract large flows of foreign direct investment, especially from Japan, and international tourists - despite periodic bouts of instability. And thanks to its "locational advantage", it has been able to attract many corporate regional headquarters. Thailand's success is particularly outstanding compared with its neighbor, the Philippines.

Despite Thailand's relative success, it has fallen into a "middle-income trap". Like the cases of several Latin American countries before it, there seems little prospect of Thailand achieving high-income status. There are many reasons for this. Thailand's education system is poor, as reflected in its low ranking in the OECD's PISA education program..$^{33}$ It has not been able to take advantage of its participation in global value chains to graduate to higher value added activities. Vietnam, Myanmar and Indonesia have recently emerged as strong competitors for Thailand. And it now has a very rapidly aging population, and the economy increasingly relies on poorly educated migrants.

Moreover, Thailand has a terribly polarized society. Income inequality is high. One of the most striking aspects of inequality is the large gaps between the poor, rural north and northeast regions, and the Bangkok area. And political instability has also been dragging the country down. It was against this background that in 2001 Thaksin Shinawatra was elected Thailand's Prime Minister, as a "champion of the poor", much to the displeasure of the Bangkok elites. Thaksin himself is not however poor. He is an extremely rich telecommunications tycoon.

Thaksin implemented pro-poor policies for infrastructure, education, public health, debt relief and microfinance. Most agree that these policies bettered the lives of poor rural north and northeastern communities. Moreover, Thaksin proved to be a politician who honored his promises to 
the poor, who still support his party strongly today. Critics of Thaksin's pro-poor policies describe them as "populist" or even vote-buying. But there was more to Thaksin than inclusive growth. Aggressive efforts to tackle the drug trade involved brutal, extrajudicial violence, and very many deaths. High-handed policies in Thailand's deep south helped fan a violent separatist insurgency. And Thaksin was seen as being extremely corrupt, even by Thai standards, for example, by exploiting government contracts. In short, Thaksin proved to be a divisive, polarizing figure, who pitted himself against the traditional Thai elite.

Thaksin was ousted in a bloodless military coup in 2006 . He was convicted of corruption, and now lives in exile in Dubai. His proxy party was re-elected in 2007. But defections led to a change of government in 2009. The Democrat Party, led by Abhisit Vejjajiva, ruled from 2009 to 2011. However, in 2011 it lost an election to Thaksin's sister Yingluck Shinawatra and her Phue Thai Party. The reign of Yingluck was also marked by controversy such as accusations of behind-the-scenes interference by Thaksin, abuse of power in government appointments, and a flawed and corrupted rice scheme that created a national financial disaster, with estimated losses of $\$ 15$ billion.

A major catalyst for further social unrest was a foolishly provocative attempt by Yingluck to pass an Amnesty Act that would have allowed Thaksin to return to Thailand without having to face a two-year jail sentence for corruption. Yingluck was removed from power in May 2014 by the constitutional court, rather than through the democratic electoral process. The military then took over in a coup, by one count the 20th coup since 1932. One of the reasons given for the coup was the violent civil unrest that had erupted between the supporters of the two main political factions: the "yellow shirts" (representing the establishment) and the "red shirts" (Thaksin and pro-democracy faction). There were rumors that royal palace members helped foment these street protests.

But the military's 2014 coup had a much bigger agenda. First, the military was determined to eliminate the Shinawatra family and the red-shirt movement from Thai political life ("de-Thaksinification"). It sees majoritarian democracy as an existential threat to its dominance of Thai political life, since the Bangkok elite does not have the numbers to win a democratic election. Indeed, Shinawatra-affiliated parties have won all elections since 2001. Yingluck was impeached in 2015 and banned from political life for five years. The military has substantially eliminated the red-shirt movement. The lese-majesty law (defaming, insulting or threatening the 
monarchy) is being freely used to curb political dissent and eliminate opposition figures. The military government is imposing widespread restrictions on freedom of speech, press and assembly, and there many reports of human rights abuses. In August 2016, the military government pushed a new constitution through a bogus referendum which tightens military rule in Thailand. In 2017, Yingluck was prosecuted for her flawed and corrupted rice scheme, but escaped the country before the judgment was handed down.

Human rights and civil rights activists, journalists and academics are in particular subject to great restrictions. For example, outspoken academic Pavin Chachavalpongpun, a Thai political scientist based in Japan, received an arrest warrant, had his passport revoked and had to apply for refugee status in Japan. His family has been intimidated, and the military government unsuccessfully asked the Japanese government to extradite him (and other similar cases) to Thailand.

Second and most importantly, the military wanted to be in control of Thailand during the succession of Thai monarch, Bhumibol Adulyadej, who died in October 2016. The King was loved and revered by most Thai people and had been a key to national stability, intervening periodically as a national conciliator in Thai politics, with the support of the military. The major problem for Thailand's royal succession was that the Crown Prince, Maha Vajiralongkorn, could never be like the semi-godlike figure of King Bhumibol. The Crown Prince is widely regarded as a playboy, with little interest in the royal court. He has not been liked by the Thai people or the military.

Thailand needs to establish a genuine majoritarian democracy, based on the rule of law, to ensure long-term political stability, and to return the country to a path of sustainable economic growth. Economic growth has been poor these past few years, averaging only around 3\% per annum. But successful majoritarian democracy requires several challenging conditions. The military should return to the barracks, and no longer intervene in national politics. Military intervention in politics is now only exacerbating Thailand's polarized society. The monarchy should also retreat from national politics.

Above all, national reconciliation and a new social contract are necessary. The Bangkok elite must recognize that the world has changed. They must learn to compromise, share the spoils of economic growth and find a new political consensus. Thanks to Thaksin, the poor from Thailand's north and northeast have tasted the benefits of inclusive growth, and many 
are willing to fight on for social justice. Further, Thailand now has a growing democracy movement thanks to its emerging middle class and better educated population, which has access to the Internet and social media, a broader political awareness and desire for political participation.

In other words, Thailand needs a new democratically elected government which governs on behalf of the whole nation, based on a new deal which is seen to be a fair deal by all major groups of society. But looking ahead, democracy's prospects in Thailand are dim. Duncan McCargo of the University of Leeds once summed up the situation neatly when he said "I've never really been more pessimistic than I am at the moment." 34

\section{Military Hangs on in Myanmar}

The poor people of Myanmar have lived through a tragic history since the country's independence from the UK in 1948. A young democracy was snuffed out by a military takeover in 1960, ushering in a regime which virtually closed the country to the rest of the world. This country of immense natural resources, which had been the world's biggest rice exporter, descended into corruption and cronyism, with much of the population living in squalid poverty and suffering from appalling human rights abuses. The economy was run by the military and its cronies, which plundered natural resources like oil and gas, jade and tropical timber, as well as trafficking in narcotics.

Civil war began at independence between the country's Bamar Buddhist ethnic majority, led by the army, and the dozens of ethnic minorities living in Myanmar's mountainous borderlands. Ethnic minorities make up one-third of the country's population. Control of Myanmar's abundant natural resources is at the heart of the conflict. The military regime virtually destroyed the country's economy, infrastructure, institutions and society.

Following student protests in 1988, the military government decided to hold elections in 1990. But it then annulled the results when the National League for Democracy (NLD) won, under the leadership of Madame Aung San Suu Kyi. She is the daughter of General Aung San, leader of Myanmar's fight for independence from Britain. The government imprisoned NLD leaders and activists. Aung San Suu Kyi would spend 15 of the next 20 years under house arrest. She was thus unable to receive the Nobel Peace Prize that she was awarded in 1991. The US and the EU began imposing heavy trade and financial sanctions on Myanmar. 
In 1989, the military regime changed the name of country from Burma to Myanmar.

In 2003, the military government outlined a seven-step roadmap to "disciplined democracy", by which the army would still retain much power. And then in 2008, it drafted a new constitution, which it had approved by a sham referendum. This is a very special constitution, through which the military is able to keep its very strong grip on national power. The army is reserved $25 \%$ of the parliamentary seats. And to change the constitution requires the votes of more than $75 \%$ of members of parliament.

The army also has the control over three powerful ministries, namely, defense, border affairs and home affairs. It nominates one of the two vicepresidents. And then there is the National Defense and Security Council which is the most powerful body in Myanmar, and can overrule the government. It has 11 members, six of whom come from the military. The military is so fearful of the popularity of Aung San Suu Kyi that it drafted a clause in the constitution that prevents her from becoming president. The clause bars anyone with a foreign spouse or children from occupying this position.

Myanmar's military dictatorship surprised the world by holding elections in 2010. These elections were however boycotted by the NLD and were won decisively by the Union Solidarity and Development Party (USDP), the main military-backed political party. The military government was thus replaced by a new military-backed civilian government led by President Thein Sein, a former military officer. Although the elections were dismissed as a sham by the international community, they paved the way for gradual political and economic reforms, and opening up of the country.

One week after the elections, Aung San Suu Kyi was released from house arrest, and agreed to cooperate with the government. And responding to public opinion, in 2011 the President suspended construction of a controversial Chinese funded hydroelectric dam. Reforms included the release of many political and other prisoners, and child soldiers. Freedom of association for trade unions was authorized, media censorship was relaxed, and ceasefire agreements were signed with eight major non-state ethnic groups, even though conflicts continue with groups like the Kachin, Shan and Wa.

Economic reforms included liberalization of foreign investment, privatization of state-owned enterprises, anti-corruption measures and exchange 
rate reform. Thanks to the opening up of the telecommunications sector, virtually everyone can now have a smartphone and Internet access. But most of the benefits of reforms have gone to urban centers like Yangon. The military and their cronies have benefited greatly from privatization and infrastructure contracts. Rural Myanmar, where some $70 \%$ of the population lives and where poverty is endemic, has been forgotten. Indeed, farmers have suffered from rising prices and land grabbing. The gap between rich and poor in Myanmar is massive.

In 2012, the NLD members, including Aung San Suu Kyi, won 43 out 45 seats in landmark parliamentary by-elections. In the same year, Barack Obama became the first US president to visit Myanmar, following a visit by Secretary of State Hillary Clinton the previous year. The US and the EU began easing many sanctions. But also in 2012, there was a wave of atrocious human rights abuses, allegedly with government complicity, against the Rohingya, a Muslim minority in the Rakhine state. More than 100,000 Rohingya became displaced people, living in refugee camps, and very many also became victims of human smuggling and trafficking, an issue we look at in Chap. 8. Most regrettably, Aung San Suu Kyi was silent on this issue, fearing a backlash from the extreme Buddhist nationalists. In 2017, the Rohingya were again victims of cruel violence from the Myanmar military. In the words of UN human rights chief Zeid Raad Al Hussein, this "seems a textbook example of ethnic cleansing". More than 600,000 Rohingya fled to Bangladesh.

In November 2015, general elections were held. The NLD won landslide majorities in both houses of parliament, with about $80 \%$ of the votes cast. According to most observers, Myanmar's elections were a resounding success, free and relatively fair. Over 6000 parliamentary candidates from 93 political parties contested the elections (but Muslim candidates were excluded from NLD lists). The outgoing president handed over power peacefully. And the head of the army, Min Aung Hlaing, supported the country's transition. Mr. Htin Kyaw, a long-term confidante of Aung San Suu Kyi, was appointed president. The army refused Miss Suu Kyi's lobbying to change the constitution to allow her to become president. She was thus appointed minister of the prime minister's office and foreign minister, as well as "state counselor", a position which she has indicated will be "above the president".

The hybrid civilian-military nature of the new government was highlighted by the remarks of army head Mr. Min Aung Hlaing at a parade on 27 March 2016 when he reminded Myanmar's citizens that the army 
"ensure[s] the stability of the country" and "has to be present in a leading role in national politics." Thant Myint-U, an historian from Myanmar, summed up the situation neatly when he said this "was not an election of a government. It was an election for a spot in a shared government with the army."

What motivated Myanmar's surprising political changes? There has been much debate and speculation about the reasons for Myanmar's surprising political changes. It seems clear that sanctions imposed by the US, EU and other countries on Myanmar's military regime had little impact. If anything, the sanctions may have hardened the resolve of the regime. As Joshua Kurlantzick and many others have argued, Myanmar's "new openness may stem from leaders' fear that they had grown too dependent on Beijing." 35 Myanmar "was becoming virtually a Chinese client state, with Beijing offering a rich source of trade, aid, investment, and diplomatic cover for Myanmar's military regime". Democratization was the only way of resuscitating relations with the US and the EU, and thus breaking the hold of China's suffocating embrace. "China sort of looks at the country as a province of China, in their sphere of influence", said Priscilla Clapp, a former US chief of mission in Myanmar. ${ }^{36}$

Another factor is that Myanmar's highly unpopular military rulers may have judged that a gradual reform process could enable them to retain their ill-gotten gains, and position of economic and political dominance, and avoid the risks of a more violent popular upheaval that several Middle East countries experienced during the Arab Spring. In this regard, Myanmar's military has been brilliantly successful. It has greatly improved public support. It has achieved an end to many sanctions and its pariah status. At the same time, the military has maintained its dominant control of the country, and has been benefiting greatly from the opening of the economy. This has been called by some as "democracy on a leash". Nevertheless, Myanmar and the lives of many of its citizens have changed immeasurably these past few years.

An optimistic scenario for Myanmar would be that continued economic development and an emerging middle class would eventually lead pressures for full democracy. A great risk for the country, however, will be the transition to a post Aung San Suu Kyi era. She is 70 years old, and despite her saintly aura, she is far from immortal. Myanmar's new politicians have no experience whatsoever in governing, and are not well placed to succeed her. (In point of fact, Aung San Suu Kyi herself has no experience in governing.) Thus, another realistic scenario is that Myanmar descends into 
political instability following her eventual passing, and that the military reasserts great control over the country. And it is still not clear that Myanmar's government and military will be able to achieve durable peace with the countries many armed ethnic groups.

Myanmar's new government faces immense challenges as the military dictatorship has left the country in a deplorable state. Despite rapid economic growth over the past decade or so, Myanmar's GDP per capita is still one of the very lowest in Asia. It has the highest poverty rate in Southeast Asia. The country's infrastructure and overall competitiveness would be among the worst in the world, and it is still one of the very most difficult countries in which to do business.

Economic wealth and power are concentrated among the army elite and their cronies. Myanmar would be one of the world's very most corrupt countries, and is one of the weakest countries when it comes to the rule of law. Myanmar is also a major center in Asia's narcotic trade, being an important source of opium and exporter of heroin, second only to Afghanistan. And since the mid-1990s, it has also become a regional source for amphetamine-type stimulants.

In short, the government faces the daunting task of trying to manage three systemic transitions - from conflict toward peace, authoritarianism toward democracy and closed economy toward an open economy. Even in the most optimistic of scenarios, it would take several decades for Myanmar to even catch up with its Southeast Asian neighbors.

The greatest challenge that the government faces is that of working with the military, which still retains great power, and is not accountable to any civilian authority. Unfortunately, a very large share of the government budget is spent on the military, at a time when it is necessary to invest massively in education, health and infrastructure. Recalibrating Myanmar's relationship with China will also be essential. While Myanmar had become overly dependent on China, cooperation with China has holds great promise for the economy, given their shared border, and Myanmar's rich endowment of natural resources, low-cost labor and access to the Indian Ocean. And with the Trump administration distracted elsewhere, China is seizing the opportunity to rebuild good relations with the Myanmar government, especially through the peace process with ethnic minorities. Lastly, great patience will be necessary, together with managing high expectations of a public who have suffered repression and lack of opportunity for over six decades. 


\section{Naïve Appeal of Authoritarian Government}

As we have argued in this chapter, democracy has very shallow roots and many enemies in Asia. But does it really matter? After all, authoritarian states like China and Singapore, as well as Korea and Taiwan before they democratized, have achieved much superior economic development than chaotic democracies like India and the Philippines. Could a "good dictatorship" a much more effective path to prosperity than democracy?

It is true that Asia has seen some "good dictators" who have been able to rush their countries up the development ladder by enlightened leadership. But a key element of their leadership has also been expanding economic freedom, such that they are often less authoritarian than they are portrayed. Also they made efforts to share the benefits of development with their citizens through education, health and other social policies. The most notable examples are Singapore's Lee Kuan Yew, China's Deng Xiaoping, Korea's Park Chung-hee, Taiwan's Chiang Kai-shek and Malaysia's Mohamad Mahathir.

But Asia has also had more than its fair share of bad dictators notably China's Mao Zedong, the military generals in Myanmar and Pakistan, and the Kim family in North Korea. And once bad dictators are in power, it can be very difficult to remove them and they can do immense damage along the way. Even after the horrors of the Great Leap Forward and the Cultural Revolution, our Chinese friends had to await the death of Mao to be rid of his murderous regime. Despite widespread agreement on Mao's many mistakes, he remains a very important symbol of the Communist Party in Xi Jinping's China. And as President Xi Jinping increasingly centralizes power, it is still not clear whether he will be a good or bad dictator. Repression at home and aggression abroad may not be a winning strategy.

Asia has also had some dictators who started strong, like the Philippines' Marcos and Indonesia's Suharto, but whose regimes deteriorated over time in terms of corruption and human rights. As dictators age, and their regimes hang on, it can be difficult for them to control the rapacious behavior of their families and cronies. Indeed, corruption which is difficult to control in any society is usually very much worse in non-democratic countries, as evidenced in the very low rankings of North Korea, Cambodia, Myanmar, Laos, Vietnam and China in Transparency International's Corruptions Perceptions Index. 
Even the poster child for Asian benevolent dictatorship, Singapore, is facing its own challenges. Living in one of the world's very richest countries, Singapore's citizens should have every reason to be happy with their lot. Nevertheless, the People's Action Party (PAP), a creation of Lee Kuan Yew, which has governed since Singapore's independence, still goes to great lengths to win elections and retain its grip on power. The PAP "uses legal harassment to deter opposition leaders from seeking office, as well as the redrawing of district boundaries to minimize support for the opposition", as Freedom House reports. ${ }^{37}$ And opposition parties are constrained by "a ban on political films and television programs, the threat of defamation suits, strict regulations on political associations, and the PAP's influence on the media and the courts ... All domestic newspapers, radio stations, and television channels are owned by companies linked to the government." Bloggers are increasingly subject to legal suits and criminal charges. One outrageous case was that of Roy Ngerng Yi Ling who was ordered to pay over $\$ 10,000$ in defamation damages to the prime minister for alleging corruption in the management of Singapore's retirement savings plan.

Although Singapore's elections have always been won by the PAP, to its great displeasure, the PAP's share of the national vote fell from over $75 \%$ in 2001 to barely $60 \%$ in 2011 . Singapore's brilliant technocrats, who had engineered the Singaporean miracle, began to stumble and seemed aloof and out of touch with their "client population." Public concerns included the dramatic increase in immigration, a straining infrastructure, housing shortages, yawning inequality, and rising poverty. In a sign that the "House of Singapore" was nervous, the government called a snap election in September 2015, one year ahead of schedule, and with only nine days for campaigning. It was clearly seeking to exploit the wave of patriotism evident in the mourning of the passing of Lee Kwan Yew six months earlier ("the LKY effect"), and the extravagant celebrations of the 50th anniversary of Singapore's independence just one month before. The government was also seeking to "cash-in" on its policies to respond to popular concerns, like restricting migration and increasing social benefits. The government's strategy was very successful, as the PAP won a resounding victory, with some $70 \%$ of the popular vote.

Despite the PAP's impressive comeback, the next phase in Singapore's political development could be problematic. The PAP's current leader is Lee Hsien Loong, the son of Lee Kuan Yew, who has led the country since 
2004 , and will retire in the coming years, and there is no obvious replacement. At the same time, infighting has broken out in the Lee family over Lee Kuan Yew's estate, and in particular his family home. Lee Kuan Yew stated in his last will that it should be demolished after his death. Prime Minister Lee Hsien Loong has, however, been pushing to preserve it as a monument, against the wishes of his two younger siblings. In a statement on Facebook, these siblings declared they no longer trusted Lee Hsien Loong as a brother and a leader. "We have lost confidence in him," the pair said. They also claimed that they "have felt threatened by Hsien Loong's misuse of his position and influence over the Singapore government and its agencies to drive his personal agenda".

While this affair may seem like a mere bagatelle, it has captivated Singapore's citizens who are used to highly disciplined and strait-laced leadership from the Lee family. It also highlights how problematic even the most efficient family dictatorships can be. History, like that of Spain under Franco, shows that the passing of heroic leaders can be the moment for a decisive move toward democracy. No-one can replace people like Franco or Lee Kwan Yew. Prime Minister Lee Hsien Loong would be wise to open up Singapore's repressive system, and allow a real democracy to flourish, as Korea and Taiwan did. The PAP would likely continue to win elections, at least for many years.

\section{Why Democracy Matters, Even in Asia}

The real lesson from Asia's successful economies like Japan, Korea, Taiwan, Singapore, Hong Kong and post-Mao China is that they all had strong, effective and meritocratic states, which built up their economies and shared the benefits of economic development with their citizens. It was not political repression that produced economic development. But even these states are now being challenged as societies are modernizing rapidly, and inequality is growing. Moreover, mature innovation-driven economies require a different type of governance from catch-up economies. Fundamentally, there is a great risk of political breakdown when the institutions of governance in authoritarian societies do not adapt sufficiently.

In this regard, there are many reasons why democracy matters for Asian development, even in China and Singapore. Continued economic development over time requires a process of creative destruction whereby new firms with new ideas and technologies can take a leading role in the economy, as firms that were successful in the past, but are no longer competitive, fade in impor- 
tance or go bankrupt. ${ }^{38}$ But creative destruction can be inhibited in authoritarian systems where there are close links between established business and political powers which protect inefficient companies, such as in China where state-owned enterprises and banks still play an important role in the economy. In short, a level playing field is necessary to foster creative destruction, and this is much more likely under an open democratic system.

In a similar vein, open democratic societies are more conducive to creativity and innovation, which are the principal drivers of all mature economies. As Michael Schuman has argued, "In order to be innovative, you need full access to information, a confidence to speak your mind and a willingness to take risks. Fear caused by political control doesn't foster an atmosphere conducive to free thinking." 39 Democratization in Korea has played a key role in enabling it to become a more innovative nation.

People like Lady Gaga, Mark Zuckerberg and Steve Jobs would find life difficult in China, as does Chinese artist Ai Weiwei who has spent long periods of time under house arrest for his politically inspired art. "Xi Jinping praises innovation in the abstract, but China's system is not set up to encourage innovation in practice" says Kerry Brown. ${ }^{40}$

Maintaining authoritarian regimes is also very, very costly. For example, social repression is very widespread in China, with typical targets being ethnic minorities like the Uighurs and Tibetans, journalists, academics, lawyers and artists. The upshot is that China spends more money on internal security than its military. Despite its friendly veneer, Singapore also invests vast resources controlling its society.

Non-democratic political systems are also prone to unstable leadership and regime transitions, which can be very destabilizing. In the past, this was a great problem in China. The country may have partly solved this issue by limiting presidents to two five-year terms. But even today, it is still a problem in China, where President XI Jinping has felt the need to eliminate his opposition figures in order to "consolidate power"-a process which has been underway ever since he took over the leadership, and with no immediate end in sight. And there are already signs that Xi Jinping may be planning to remain at the leadership of China after two-term limit. This shows that authoritarian regimes like China are fundamentally more fragile than they might appear. In contrast, Prime Minister Narendra Modi had a very smooth transition to power in India thanks to the country's democratic institutions.

Perhaps the most important reason why democracy matters is that, even if many upper- and middle-class Asians are happy with their lot, 
growing numbers of Asians, especially youth, are demanding freedom, rule of law, clean governance and democracy. You only have to look at the activism today in Hong Kong, Korea, Malaysia, Taiwan and Thailand, as well as many parts of China. And a simple conversation with a poor person in the street in India will reveal how proud Indians feel about their democracy, especially when compared with the case of China.

One of the many consequences of Asia's flawed politics is that the region has become one of the centers of the global criminal economy. In the next chapter, we review Asia's involvement in counterfeiting and piracy, illegal drug production and trafficking, environmental crime, human trafficking and smuggling, corruption, money laundering and cybercrime.

\section{Notes}

1. openDemocracy. An artist's duty: an interview with Ai Weiwei, 6 January 2014.

2. Economist Intelligence Unit. Democracy Index 2016: Revenge of the deplorables.

3. Reporters Without Borders. 2017 World Press Freedom Index.

4. Lipset, Seymour Martin. Some Social Requisites of Democracy: Economic Development and Political Legitimacy. The American Political Science Review Vol. 53, No. 1 (Mar., 1959), pp. 69-105.

5. Inglehart, Ronald and Christian Welzel. How Development Leads to Democracy: What We Know About Modernization. Foreign Affairs, March/April 2009.

6. Gurria, Angel. The OECD and Korea: Celebrating a milestone. OECD Observer, October 2016.

7. de Mesquita, Bruce Bueno and George W. Downs. Development and Democracy. Foreign Affairs, September/October 2005.

8. OECD. International Migration Outlook 2012.

9. Kurlantzick, Joshua. Southeast Asia's Regression from Democracy and Its Implications. Council on Foreign Relations, May 2014.

10. US Department of State. Country Reports on Human Rights Practices for 2015.

11. Xinhua. China issues report on U.S. human rights, 9 March 2017.

12. New Perspectives Quarterly. The China Model: A Dialogue between Francis Fukuyama and Zhang Weiwei. Fall 2011. 
13. Fallows, James. China's Great Leap Backward. The Atlantic, December 2016.

14. Human Rights Watch. World Report 2016.

15. Goebel, Christian, and Lynette H. Ong. Social Unrest in China. Europe China Research and Advice Network, August 2012.

16. Chang, Gordon G. (2001). The Coming Collapse of China.

17. Pei, Minxin. 5 Ways China Could Become a Democracy. The Diplomat, 13 February 2013.

18. Pei, Minxin. Xi's war on corruption could hasten Chinese Communist Party's fall. Nikkei Asian Review, 4 June 2015.

19. Shambaugh, David (2016). China's Future.

20. West, John. Kim Dae-jung: A tribute. OECD Observer, November 2009.

21. Freedom House. Freedom in the World 2016.

22. Johnston, Donald. J. To the Miracle on the Han. OECD Observer, October 2016.

23. Reporters Without Borders. 2016 World Press Freedom Index.

24. Trade Union Advisory Committee to the OECD (TUAC). 20TH Anniversary of Korean OECD membership overshadowed by labour rights and freedom of assembly violations.

25. Denney, Steven. South Korea at a Crossroads. The Diplomat, 24 February 2017.

26. Villaseca, Matias. Bonsai Democracy: Looking Into the Evolution of Japan's Government. Research Discourse, Spring 2011.

27. The National Diet of Japan (2012). The official report of The Fukushima Nuclear Accident Independent Investigation Commission.

28. Repeta, Lawrence. Japan's Democracy at Risk-The LDP's Ten Most Dangerous Proposals for Constitutional Change. The Asia-Pacific Journal, Vol. 11, Issue 28, No. 3, 15 July 2013.

29. Sugimoto, Yoshio (2010). An Introduction to Japanese Society.

30. West, John. Is the Philippines about to realise its FDI potential? FDIIntelligence, 1 December 2015.

31. US Department of State. Philippines 2015 Crime and Safety Report.

32. Heydarian, Richard Javad. The Philippines and America: A Tale of Two (Troubled) Democracies. The World Post, 24 October 2016.

33. OECD. Programme for International Student Assessment, 2015 Results.

34. Brookings. Kingdom at a crossroads: Thailand's uncertain political trajectory, 24 February 2016.

35. Kurlantzick, Joshua. The Mysterious Opening of Myanmar. Council on Foreign Relations, 4 December 2011.

36. Brookings. The struggle for democracy in Myanmar/Burma, 14 July 2015.

37. Freedom House. Freedom in the World 2016. 
38. Acemoğlu, Daron, and James A. Robinson (2012). Why Nations Fail.

39. Schuman, Michael. Is democracy necessary for economic success? Time, 5 November 2010.

40. Brown, Kerry. Why China Can't Innovate. The Diplomat, 19 August 2014.

Open Access This chapter is licensed under the terms of the Creative Commons Attribution 4.0 International License (http://creativecommons.org/licenses/ by $/ 4.0 /$ ), which permits use, sharing, adaptation, distribution, and reproduction in any medium or format, as long as you give appropriate credit to the original author(s) and the source, provide a link to the Creative Commons license and indicate if changes were made.

The images or other third party material in this chapter are included in the chapter's Creative Commons license, unless indicated otherwise in a credit line to the material. If material is not included in the chapter's Creative Commons license and your intended use is not permitted by statutory regulation or exceeds the permitted use, you will need to obtain permission directly from the copyright holder.

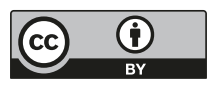

